\title{
Relationship between Players Involvement in Games and Societal Progressive Growth
}

\author{
at High Level \\ * Zulfiqar Ali, PET \\ ** Dr. Farooq Hussain, Assistant Professor (Corresponding Author) \\ *** Shagufta Javed Khan, Director Physical Education
}

\begin{abstract}
The point of this study to investigate the impact of sports support on social improvement at an optional level in the region Muzaffarabad. The goals of the investigation were to discover the effect of sports interest on social improvement of the understudies (enrolled students) at the auxiliary level in District Muzaffarabad, Azad Jammu and Kashmir and to look at the social improvement of male and female understudies partaking in sports. The population of the study was all competitors while 444 of them were taken as a sample. The test of the examination comprised of 444 competitor understudies from chosen public area auxiliary schools of region Muzaffarabad through purposive inspecting. A self-created poll comprised of 35 shut finished inquiries was utilized as information Honesty estimated on a five-point Likert scale. The study was delimited to auxiliary schools of Muzaffarabad. The outcome demonstrated that there is no contrast between the social advancement of male and female competitor understudies at auxiliary school level in area Muzaffarabad. Noteworthy effect of sports support was found on social advancement in athletes' i.e. Self-conduct, friendship, socialconduct, building certainty and honesty at auxiliary level in region Muzaffarabad
\end{abstract}

Keywords: Sports, Players' involvement, Social Improvement

\section{Introduction}

Participation in sport is a means of exposing adolescents to a pro-social environment that promotes core values such as fair play, athleticism, competitiveness, and achievement (Taylor et al., 2015). Participation in sport can also influence attitudes and behavior, reducing the impact of negative effects that can lead to antisocial behavior and / or experimentation with smoking, alcohol, and illicit drugs (Audit Commission, 2009). Because sports programs are offered during school and weekend periods, which are often associated with "endangered" opportunities for negative behavior, sport offers an attractive way to take up adolescents 'time to achieve a number of positive personal and social outcomes (Gao et al., 2011). Sport not only offers improvement in fitness but also advancement in social attitude (Baciu \& Baciu, 2015). Sports involvement improves individual, ethical, and communal understanding in players (Macphail, Gorely, \& Kirk, 2003).

Physical activity produces beneficial effects on health maintenance, tone, and personality development also. Consequently, time has validated the positive effects of physical activity and sport on self-concept, self-behavior, anxiety, depression, pressure and stress, self-confidence, energy, mood, efficiency, and wellbeing. Sport and physical activity have contributed to the socialization of men especially young people, in circumstances where there is good control. Also, it has been said that socialization in sports can be promoted only when there are highlighted moral qualities, attitudes, skills, and rules assimilated in physical activities that can be transferred to any other social sphere and can be adapted to the specifics of any other social institution. Sports and physical education promote respect for moral values in both the Olympic spirit and the core values of life in the community, thereby fostering the integration of the group, society, and communication skills. (Turcu \& Todor, 2010).

Many important skills are learned by young people through team sport, and one of them is competition. Nowadays, we face competition every day in every domain. As adults face competition

* $\quad$ Elementary and Secondary Department KPK Email: zulfiqar353@ gmail.com

** Department of Physical Education and Sports, Abdul Wali Khan University Mardan

Email: farooqhussain@awkum.edu.pk

*** Elementary and Secondary Department KPK 
when looking for a job or trying to be better at their jobs, children are also facing competition in school in acquiring good grades and becoming the best in sport activity. Therefore, competition can give children the chance to find a healthy way to live and an opportunity to find new friends at an early age. Besides, it seems that children who participate in sports activities have more chances to emerge best in competitions in other areas of their life (Gemar, 2020).

Physical activities unite the participants and help in improving their relationships, their communication skills and socializing with others, and making long-lasting friendships (Sabin \& Marcel, 2014). The associations found for participation in competitive sport and physical activity often yield multiple benefits. Bailey et al (2013) recognized that such benefits are not autonomous, independent, or disconnected, but instead reinforce each other. The purpose of the study to investigate relationship between games involvement of teenagers and progress of societal attitudes.

\section{Research Methodology}

This part incorporates the strategy and approach embraced in leading this exploration. It incorporates populace, test, research instrument, legitimacy and dependability of the instrument, information assortment technique, information examination, and understanding. This is a descriptive study to investigate the effect of one variable (sports support) on another variable (social turn of events). Review strategy was received for this examination because the majority of the social investigates are done through this technique (Groves, Fowler, Couper, Lepkowski, Singer \& Tourangeau, 2004).

\section{Population}

Populace is a finished arrangement of components (people or items) that have some basic trademark characterized by the testing rules set up by the scientist (Cohen, Manion \& Morison, 2000). The target populace of the current examination was optional level competitor understudies of public area schools of District Muzaffarabad, Azad Jammu, and Kashmir. There are 6000sports member understudies took on the auxiliary school level in locale Muzaffarabad, Directorate of Education, meeting 20162018 in leading group of middle of the road and optional instruction Mirpur AJK.

\section{Sample}

A sample of 444 understudies was drawn by utilizing a defined irregular inspecting strategy from 18 male and 13 females' schools in Muzaffarabad. Among this sample, 277 were men and 167 were women sportsmen.

\section{Research Instrument}

A stand-alone survey for non-commissioned officers used for a wide range of information on sports support and their social development. Polling is a research tool for a wide range of data through a vast example (Burgess, 2001).

The poll contains 35 close-ups, transmitted in five subgroups: Self-Conduct (Things 1-8), Friendship (Things 9-15), Social Behavior (Things 16-23). Building Security (Things 24-27) and Honesty (Things 29-35).

\section{Instrument and its Validity}

The analyst has read the applicable writing for the improvement of the survey. The examination chief and specialists in this field were counseled for content. Legitimacy of the scale rundown of specialists is connected as.

\section{Reliability of the Instrument}

To check the inward consistency among things of instrument, Cronbach alpha was applied by utilizing SPSS V. 16. They got Cronbach alpha for the scale was $\alpha=0.81$.

\section{Data Collection}

The specialist controlled the poll to gather the information. The analyst thought about the poll literally to the respondents to guarantee a hundred percent return. Poll was just conveyed to understudies and got back from sports member understudies of auxiliary level

\section{Analysis and Interpretation of Data}

After the information was correctly associated, a sequential classification was made. The information was dissected using SPSS (Statistical Package for Social Sciences) version 16. The t-test of the illustrative measurements was used as a factual method to examine the information. SPSS was used to calculate the estimate. (A test is used to find the huge contrast between the average scores of the two collections. 


\section{Analysis and Interpretation of Data}

This section manages the investigation of information acquired through a survey from the respondent on the impact of interest in sport on social development in the public space of Muzaffarabad AJK at the auxiliary level of public schools for men and women. For information on clear insights utilizing rate, mean score, and inferential measurements t-test. The dissected information is introduced as below.

Table 4.1 Sportsmen' view regarding the effect of athletic involvement on social attitude

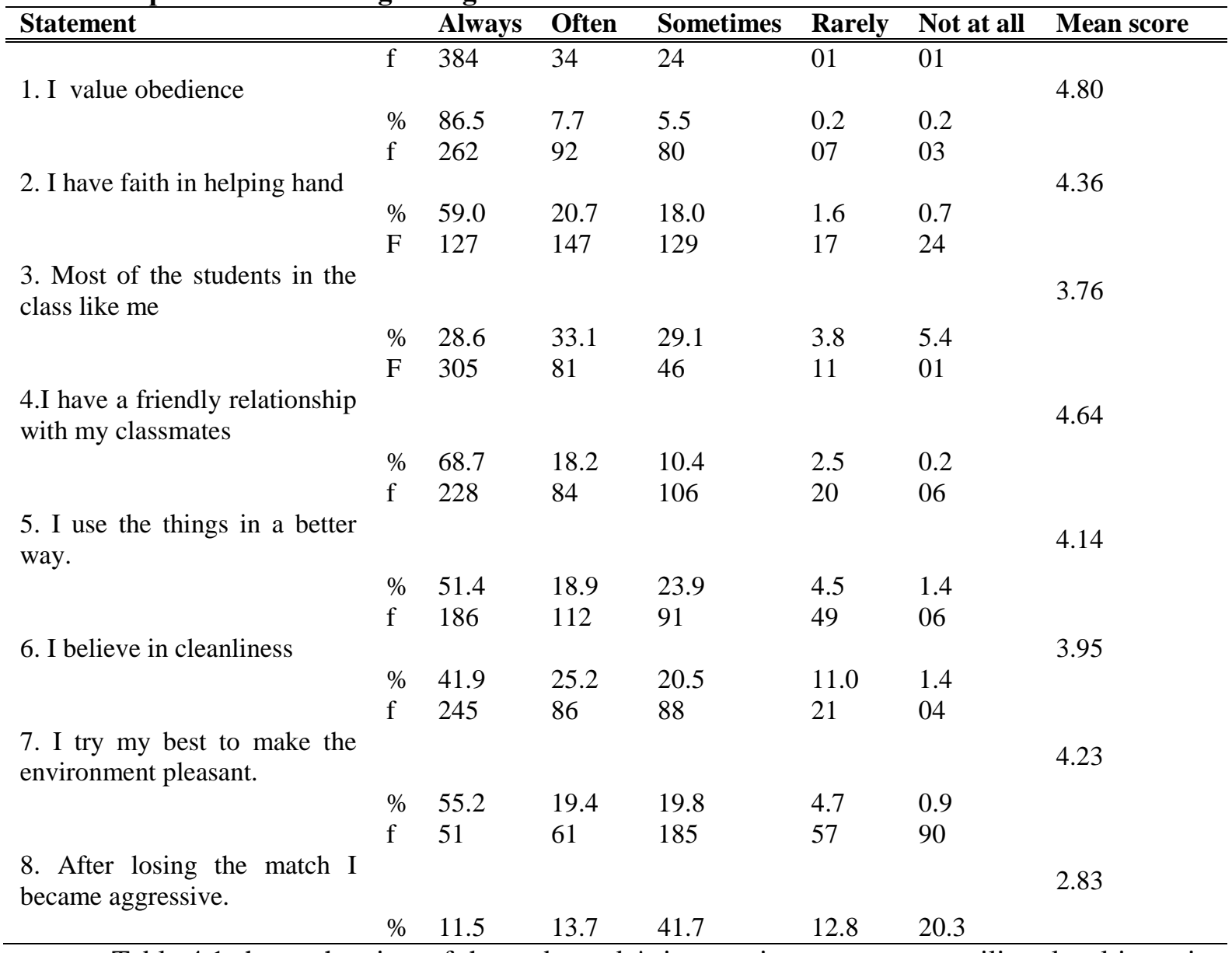

Table 4.1 shows the view of the understudy's interest in sports at an auxiliary level in region Muzaffarabad. Table 4.1 shows that $86.5 \%$ consistently prefer to obey the teachers.7.7 \% of understudies frequently prefer to obeying instructors. $5.5 \%$ understudies here and there complying with their educators. Just $0.2 \%$ of understudies once in a while prefer to comply with the instructors, similarly, $0.2 \%$ of understudies do not care to comply with the educators.

$59.0 \%$ consistently like to help their classmates.20.7\% regularly like to help their classmates.18.0 \% once in a while like to help their classmates $1.6 \%$ rarely like to help their schoolmates. $0.7 \%$ does not care to help their cohorts.

$28.6 \%$ of understudies recommend that the greater part of the understudies in their group consistently enjoyed him. $33.1 \%$ of understudies propose that the majority of the understudies in their group regularly loved him. $29.1 \%$ of understudies recommend that the vast majority of the understudies in their group some of the time enjoyed him.3.8 \% students propose that the greater part of the understudies in their group once in a while preferred him and just $5.4 \%$ of understudies recommend that a large portion of the understudies in their group don't love him.

$68.7 \%$ of understudies recommend that they have in every case the neighborly relationship with their cohorts. $18.2 \%$ of understudies propose that they have regularly cordial relationships with their group mates.10.4\% of understudies recommend that they have at some point inviting relationships with their cohorts. $2.5 \%$ of understudies recommend that they have an infrequently amicable relationship with their cohorts and just $0.2 \%$ of understudies propose that they do not have an inviting relationship with their colleagues. 
$51.4 \%$ of understudies propose that they generally utilize the things in a superior manner. $18.9 \%$ of understudies recommend that they frequently utilize the things in a superior manner. $23.9 \%$ of understudies recommend that they once in a while utilize the things in a superior way. $4.5 \%$ of understudies propose that they infrequently utilize the things in a superior manner and just $1.4 \%$ of understudies recommend that they don't utilize the things in a superior manner.

$41.9 \%$ of understudies propose that they generally attempt to keep the streets, stops and transport stands, and so on perfect and clean.25.2\% of understudies recommend that they frequently attempt to keep the streets, stops and transport stands, and so forth perfect and clean. $20.5 \%$ of understudies recommend that they are here and their attempt to keep the streets, stops and transport stands, and so on slick and clean.11.0 \% understudies propose that they seldom attempt to keep the streets, stops and transport stands and so on flawless and perfect and just $1.4 \%$ students recommend that they do not attempt to keep the streets, stops and transport stands and so forth perfect and clean.

$55.2 \%$ of understudies recommend that they generally make an honest effort to make their current circumstance pleasant.19.4\%students propose that they regularly make an honest effort to make their current circumstance pleasant. $19.8 \%$ of understudies recommend that they here and there make an honest effort to make their current circumstance pleasant. $4.7 \%$ of understudies recommend that they once in a while make an honest effort to make their current circumstance pleasant. $0.9 \%$ of understudies recommend that they don't make an honest effort to make their current circumstance lovely.

$11.5 \%$ of understudies at the optional level recommend that after losing a match they generally got forceful. $13.7 \%$ of sports understudies at auxiliary level propose that in the wake of losing a match they frequently got forceful. $41.7 \%$ of understudies at auxiliary level propose that after losing a match they now and then got forceful. $12.8 \%$ of understudies at the optional level recommend that after losing a match they infrequently became forceful and just $20.3 \%$ of understudies at the auxiliary level propose that in the wake of losing a match they never got forceful.

Table 4.2 Sportsmen' view regarding the effect of athletic involvement on social attitude

\begin{tabular}{|c|c|c|c|c|c|c|c|}
\hline Statement & & Always & Often & Sometimes & Rarely & Not at all & Mean score \\
\hline \multirow{4}{*}{ 9. I am social genius. } & f & 283 & 1112 & 35 & 12 & 02 & \multirow{4}{*}{4.49} \\
\hline & & & & & & & \\
\hline & $\%$ & 63.7 & 25.2 & 7.9 & 2.7 & 0.5 & \\
\hline & $\mathrm{f}$ & 169 & 108 & 107 & 31 & 29 & \\
\hline \multirow[t]{3}{*}{$\begin{array}{l}\text { 10. I have many friends in } \\
\text { my Mohalla/surrounding. }\end{array}$} & & & & & & & \multirow[t]{3}{*}{3.80} \\
\hline & $\%$ & 38.1 & 24.3 & 24.1 & 07 & 6.5 & \\
\hline & $\mathrm{f}$ & 122 & 101 & 148 & 55 & 18 & \\
\hline \multirow[t]{3}{*}{$\begin{array}{l}\text { 11. I accompany my mates } \\
\text { for a picnic }\end{array}$} & & & & & & & \multirow[t]{3}{*}{3.57} \\
\hline & $\%$ & 27.5 & 22.7 & 33.3 & 12.4 & 4.1 & \\
\hline & $\mathrm{f}$ & 97 & 130 & 144 & 41 & 32 & \\
\hline \multirow[t]{3}{*}{$\begin{array}{l}\text { 12.My friends help me in } \\
\text { difficulties }\end{array}$} & & & & & & & \multirow[t]{3}{*}{$3 ; 49$} \\
\hline & $\%$ & 21.8 & 29.3 & 32.4 & 9.2 & 7.2 & \\
\hline & $\mathrm{f}$ & 126 & 100 & 116 & 37 & 65 & \\
\hline \multirow[t]{3}{*}{$\begin{array}{l}\text { 13. My colleagues treat me } \\
\text { in illness. }\end{array}$} & & & & & & & \multirow[t]{3}{*}{3.42} \\
\hline & $\%$ & 28.4 & 22.5 & 26.1 & 8.3 & 14.6 & \\
\hline & $\mathrm{f}$ & 89 & 69 & 149 & 59 & 78 & \\
\hline \multirow[t]{3}{*}{$\begin{array}{l}\text { 14. My friends help in } \\
\text { shifting goods. }\end{array}$} & & & & & & & \multirow[t]{3}{*}{3.07} \\
\hline & $\%$ & 19.9 & 15.5 & 33.6 & 13.3 & 17.6 & \\
\hline & $\mathrm{f}$ & 105 & 77 & 128 & 67 & 67 & \\
\hline \multirow[t]{2}{*}{$\begin{array}{l}\text { 15. My friends help me in } \\
\text { need. }\end{array}$} & & & & & & & \multirow[t]{2}{*}{3.25} \\
\hline & $\%$ & 3.5 & 17.3 & 28.8 & 15.1 & 15.1 & \\
\hline
\end{tabular}

Table 4.2 shows that $63.7 \%$ of understudy at the auxiliary level in locale Muzaffarabad consistently have companion transport in schools.25.2\% of understudies frequently have companion transport in school.7.9 \% of sports partook understudies in some cases have companion transport in 
school at optional level, while $2.7 \%$ understudies seldom have kinship in their schools and just $0.5 \%$ understudy at optional level in area Muzaffarabad don't have any companion transport in school.

$38.1 \%$ understudies at an optional level in region Muzaffarabad consistently have numerous companions in their Mohalla/surrounding.24.3\% understudies at auxiliary level frequently have numerous companions in their Mohalla/surrounding. $24.1 \%$ understudies at an auxiliary level some of the time have numerous companions in their Mohalla/encompassing, while $07 \%$ understudies at an optional level seldom have numerous companions in their Mohalla/encompassing and just $6.5 \%$ understudies at auxiliary level in area Muzaffarabad don't have numerous companions in their Mohalla/encompassing. $27.5 \%$ of understudies at an optional level in area Muzaffarabad proposed that when they organize an excursion program, they in every case effectively discover companions to join them.22.7 \% of understudies at auxiliary level recommended that when they orchestrate an outing program, they regularly effectively discover companions to join them.33.3\% of understudies at the optional level recommended that when they mastermind an outing program, they now and again effectively discover companions to go along with them while $12.4 \%$ of understudies at the optional level recommended that when they mastermind a cookout program, they infrequently discover companions to go along with them and just $4.1 \%$ understudies at an auxiliary level in locale Muzaffarabad proposed that when they orchestrate an outing program, they don't effortlessly discover companions to go along with them.

$21.8 \%$ of understudies at auxiliary level in region Muzaffarabad recommend that if they were in a difficult situation, they in every case effectively discover somebody who helped them. $29.3 \%$ of understudies at the optional level recommend that if they were in a tough situation, they regularly effectively discover somebody who helped them.32.4\% of understudies at auxiliary level propose that if they were in a difficult situation, they in some cases effectively discover somebody who helped them, while $9.2 \%$ of understudies at auxiliary level recommends that if they were in a difficult situation, they seldom discover somebody who helped them, and just $7.2 \%$ of understudies at an auxiliary level in area Muzaffarabad recommend that if they were in a tough situation, they don't discover somebody who helped them.

$28.4 \%$ of understudies at auxiliary level in area Muzaffarabad recommend that on the off chance that they were debilitated, a significant number of their companions consistently came to see them. $22.5 \%$ of understudies at the optional level propose that on the off chance that they were debilitated, a significant number of their companions regularly came to see them. $26.1 \%$ understudies at auxiliary level recommend that on the off chance that they were wiped out, a considerable lot of their companions in some cases came to see them, while $8.3 \%$ understudies at auxiliary level recommend that on the off chance that they were wiped out, a significant number of their companions seldom came to see them and just $14.6 \%$ understudies at an optional level in region Muzaffarabad recommend that if they were wiped out, their companions don't come to see them.

$19.9 \%$ of understudies at an optional level in locale Muzaffarabad propose that on the off chance that they expected to move another house, they in every case effortlessly discovered a few companions who helped them in moving the household merchandise. $15.5 \%$ of understudies recommend that on the off chance that they expected to move another house, they frequently effectively discovered a few companions who helped them in moving the household goods.33.6\% understudies at auxiliary level propose that on the off chance that they expected to move another house, they in some cases effortlessly discovered a few companions who helped them in moving the household merchandise, while $13.3 \%$ understudies at optional level propose that on the off chance that they expected to move another house, they seldom discovered a few companions who helped them in moving the household products and just $17.6 \%$ understudies at an optional level in area Muzaffarabad recommend that on the off chance that they expected to move another house, they don't discover a few companions who helped them in moving the household products.

$23.6 \%$ of understudies at auxiliary level in region Muzaffarabad recommend that if they required a bicycle or vehicle critically, they in every case handily discovered somebody who loan them. $17.3 \%$ of understudies at the optional level propose that if they required a bicycle or vehicle earnestly, they frequently effortlessly discovered somebody who loan them. $28.8 \%$ of understudies at optional level propose that if they required a bicycle or vehicle direly, here and there they discovered somebody who loans them, while $15.1 \%$ of understudies at auxiliary level recommend that if they required a bicycle or vehicle desperately, they infrequently discovered somebody who loan them and 
just $15.1 \%$ understudies at an auxiliary level in area Muzaffarabad recommend that if they required a bicycle or vehicle earnestly, they don't discover somebody who loans them.

Table 4.3 Sportsmen' view regarding the effect of athletic involvement on social attitude

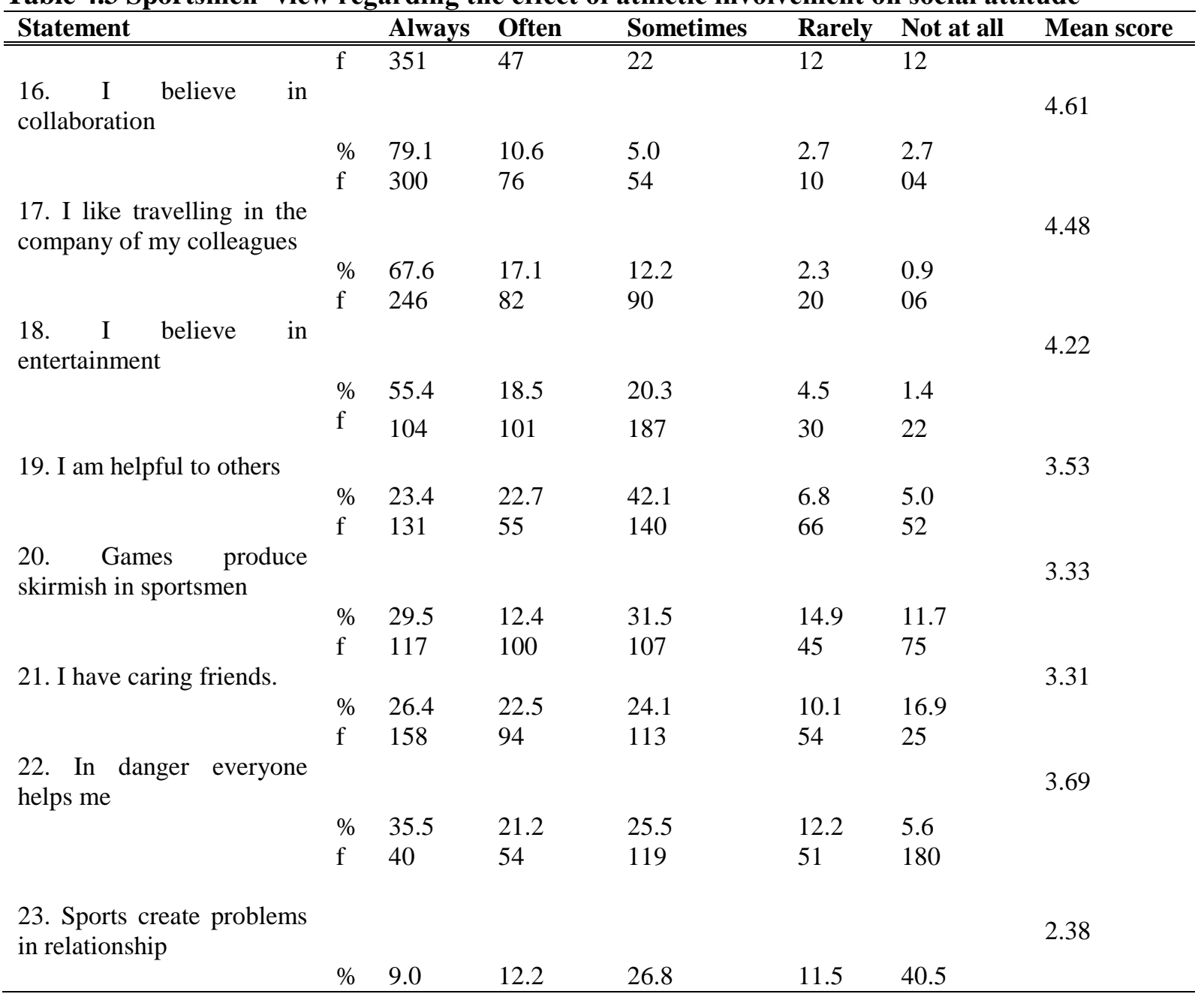

Table 4.3 shows that $79.1 \%$ of understudies (sports members) consistently like working in gatherings or groups in schools at auxiliary level in locale Muzaffarabad. $10.6 \%$ understudies regularly like working in gatherings or groups, $5.0 \%$ understudies some of the time like working in gatherings or colleagues in schools. Just $2.7 \%$ of understudies rarely like to work in gathering or group. Similarly, $2.7 \%$ of understudies do not care to work in a gathering or group.

$67.6 \%$ of understudies consistently prefer to appreciate cookout with companions at optional schools' level in area Muzaffarabad.17.1\% understudies frequently prefer to appreciate outing with their friends. $12.2 \%$ some of the time like to appreciate excursion with their companions at school's level, while $2.3 \%$ understudies seldom prefer to appreciate cookout with companions in schools, and just $0.9 \%$ of students don't care to appreciate outing with companions at auxiliary schools' level in locale Muzaffarabad.

$55.4 \%$ of understudies consistently appreciate investing energy with their companions at auxiliary school level in area Muzaffarabad. $18.5 \%$ of understudies regularly appreciate investing energy with their companions. $20.3 \%$ of understudies here and there prefer to appreciate investing energy with companions in schools. While $4.5 \%$ of understudies seldom prefer to appreciate investing energy with companions and just $1.4 \%$ understudies do not care to appreciate investing time with their companions at an optional level in locale Muzaffarabad

$23.4 \%$ of understudies consistently get welcomed to get things done with others at an optional level in region Muzaffarabad. $22.7 \%$ of understudies regularly get welcomed to get things done with others in their schools. $42.1 \%$ of understudies once in a while get welcomed to get things done with different people groups. While $6.8 \%$ of understudies infrequently get welcomed to get 
things done with different people groups and just $5 \%$ of understudies do not prefer to get welcome to get things done with different people groups at auxiliary level schools in region Muzaffarabad.

The impression of $29.5 \%$ of students is, that the games consistently make struggle among the players at auxiliary level in locale Muzaffarabad.12.4\% understudies regularly believe that sports make strife among the players. $31.5 \%$ of understudies in some cases believe that the games make strife among the players at auxiliary school level in area Muzaffarabad. While $14.9 \%$ understudies infrequently imagine that the games struggle among the players and just $11.7 \%$ understudies never believe that the game makes strife among the players at auxiliary level in area Muzaffarabad. Perception of $26.4 \%$ of students in their nonappearance, consistently companions/relative care for their homes. $22.5 \%$ of understudies frequently recommend that in their nonattendance companion/relative care for their homes. $24.1 \%$ understudies now and then suggest that in their nonappearance companion/relative care for their homes. While $10.1 \%$ understudies infrequently suggest that in their nonattendance companion/relative takes care of their homes and $16.9 \%$ of understudies imagine that in their nonappearance nobody cares for their homes.

View of $35.5 \%$ understudies that consistently numerous individuals ready to assist them in the hour of crisis. $21.2 \%$ understudies feels that frequently numerous individuals ready to assist them in the hour of crisis. $25.5 \%$ understudies believes that occasionally numerous individuals ready to assist them in the hour of emergency. While $12.2 \%$ of understudies imagine that seldom individuals ready to assist them in the hour of emergency and just $5.6 \%$ of understudies feel that never individuals ready to assist them in the hour of emergency at optional school's level in area Muzaffarabad.

$09 \%$ understudies feel that consistently Sports make issues in relationship. $12.2 \%$ understudies propose that frequently sports make issues in relationship, $26.8 \%$ understudies in some cases believe that sports make issues in relationship while $11.5 \%$ understudies infrequently imagine that sports make issues in relationship $40.5 \%$ understudies at auxiliary school level

Table 4.4 Sportsmen' view regarding the effect of athletic involvement on social attitude

\begin{tabular}{|c|c|c|c|c|c|c|c|}
\hline Statement & & Always & Often & Sometimes & Rarely & Not at all & Mean score \\
\hline \multirow{4}{*}{$\begin{array}{l}\text { 24. I am bold before } \\
\text { instructor }\end{array}$} & $\overline{f f}$ & 198 & 90 & 93 & 19 & 44 & \\
\hline & & & & & & & 3.85 \\
\hline & $\%$ & 44.6 & 20.3 & 20.9 & 4.3 & 9.9 & \\
\hline & $\mathrm{f}$ & 136 & 85 & 164 & 34 & 25 & \\
\hline \multirow[t]{3}{*}{$\begin{array}{l}\text { 25. I make judgment } \\
\text { myself }\end{array}$} & & & & & & & 3.61 \\
\hline & $\%$ & 30.6 & 19.1 & 36.9 & 7.7 & 5.6 & \\
\hline & $\mathrm{f}$ & 152 & 96 & 127 & 45 & 24 & \\
\hline \multirow[t]{3}{*}{$\begin{array}{l}\text { 26. I am resilient in bad } \\
\text { situation }\end{array}$} & & & & & & & 3.69 \\
\hline & $\%$ & 34.2 & 21.6 & 28.6 & 10.1 & 5.4 & \\
\hline & $\mathrm{f}$ & 86 & 88 & 170 & 54 & 46 & \\
\hline \multirow[t]{3}{*}{$\begin{array}{l}27 . \text { I am problem solver } \\
\text { for others }\end{array}$} & & & & & & & 3.26 \\
\hline & $\%$ & 19.4 & 19.8 & 38.3 & 12.2 & 10.4 & \\
\hline & $\mathrm{f}$ & 201 & 96 & 102 & 24 & 21 & \\
\hline \multirow[t]{2}{*}{$\begin{array}{l}\text { 28. I face challenges } \\
\text { with smile }\end{array}$} & & & & & & & 3.92 \\
\hline & $\%$ & 45.3 & 21.6 & 23.0 & 5.4 & 4.7 & \\
\hline
\end{tabular}

Table 4.4 shows that $44.6 \%$ of understudies consistently accept that they are not scared of posing inquiries from their teachers. $20.3 \%$ understudies regularly accept that they are not terrified of posing inquiries from their instructors, $20.9 \%$ understudies at times accept that they are not terrified of posing inquiries from their educators, while $4.3 \%$ understudies consistently accept that they are seldom not scared of posing inquiries from their instructors and just $9.9 \%$ understudies accept that they are never scared of posing inquiries from their instructors at an auxiliary level in region Muzaffarabad.

$30.6 \%$ understudies consistently settle on their own choices at auxiliary level in locale Muzaffarabad.19.1\% competitor understudies frequently settle on their own choices. $36.9 \%$ 
understudies at an optional level now and again settle on their own choices while $7.7 \%$ understudies infrequently settle on their own choices and just $5.6 \%$ understudies never settle on their own choices at auxiliary level in area Muzaffarabad.

$34.2 \%$ of understudies recommend that on the off chance that they took off alone at a more abnormal spot; consistently they can deal with the circumstance strikingly. $21.6 \%$ of understudies propose that if they took off alone at a more bizarre spot, regularly they can deal with the circumstance strongly. $28.6 \%$ of understudies recommend that if they took off alone at a more abnormal spot, in some cases they can deal with the circumstance intensely while $10.1 \%$ of understudies propose that on the off chance that they took off alone at a more interesting spot, seldom they can deal with the circumstance strikingly and just $5.4 \%$ understudies propose that on the off chance that they took off alone at a more odd spot, never they can deal with the circumstance strongly.

$19.4 \%$ of understudies recommend that numerous individuals consistently contact with them to tackle their concern at an auxiliary level in area Muzaffarabad.19.8 \% of understudies propose that numerous individuals frequently contact with them to take care of their concern at an optional level in region Muzaffarabad. $38.3 \%$ understudies recommend that occasionally numerous individuals contact with them to tackle their concern at an auxiliary level in region Muzaffarabad

While $12.2 \%$ understudies propose that individuals infrequently contact with them to take care of their issues and just $10.4 \%$ understudies recommend that individuals never contact with them to take care of their concern at an optional level in locale Muzaffarabad.

$45.3 \%$ understudies consistently not terrified of the difficulties in life at an auxiliary level in locale Muzaffarabad.21.6\% understudies regularly not scared of the difficulties in life at an optional level in region Muzaffarabad.23.0 \% understudies some of the time not terrified of the difficulties throughout everyday life, while $5.4 \%$ understudies seldom not scared of the difficulties throughout everyday life and just $4.7 \%$ understudies never, not scared of the difficulties in life at auxiliary level in region Muzaffarabad.

Table 4.5 Sportsmen' view regarding the effect of athletic involvement on social attitude

\begin{tabular}{|c|c|c|c|c|c|c|c|}
\hline Statement & - & Always & Often & Sometimes & Rarely & Not at all & Mean score \\
\hline & $f$ & 207 & 64 & 144 & 13 & 16 & \multirow[b]{2}{*}{3.98} \\
\hline \multirow[t]{2}{*}{$\begin{array}{l}\text { 29. I keep balance my } \\
\text { words and actions } \\
\text { always say what I feel }\end{array}$} & & & & & & & \\
\hline & $\%$ & 46.6 & 14.4 & 32.4 & 2.9 & 3.6 & \\
\hline \multirow{4}{*}{$\begin{array}{l}\text { 30. My coach has faith } \\
\text { in me }\end{array}$} & $\mathrm{f}$ & 314 & 72 & 44 & 06 & 08 & \multirow{3}{*}{4.53} \\
\hline & & & & & & & \\
\hline & $\%$ & 70.7 & 16.2 & 9.9 & 1.4 & 1.8 & \\
\hline & $\mathrm{f}$ & 393 & 32 & 13 & 02 & 04 & \multirow[b]{2}{*}{4.82} \\
\hline \multirow[t]{3}{*}{$\begin{array}{l}\text { 31. My father and } \\
\text { mother believe in me }\end{array}$} & & & & & & & \\
\hline & $\%$ & 88.5 & 7.2 & 2.9 & 0.5 & 0.9 & \\
\hline & $\mathrm{f}$ & 300 & 82 & 49 & 07 & 06 & \multirow{2}{*}{4.49} \\
\hline \multirow{2}{*}{ 32. I trust my friends } & $\%$ & 67.6 & 18.5 & 11.0 & 1.6 & 1.4 & \\
\hline & $\mathrm{f}$ & 268 & 66 & 74 & 14 & 22 & \multirow[b]{2}{*}{4.23} \\
\hline \multirow[t]{3}{*}{$\begin{array}{l}\text { 33. I guard secrets of } \\
\text { others }\end{array}$} & & & & & & & \\
\hline & $\%$ & 60.4 & 14.9 & 16.7 & 3.2 & 5.0 & \\
\hline & $\mathrm{f}$ & 111 & 84 & 175 & 40 & 34 & \\
\hline \multirow{3}{*}{$\begin{array}{l}\text { 34. I share matter with } \\
\text { my colleagues }\end{array}$} & & & & & & & \multirow[t]{2}{*}{3.45} \\
\hline & $\%$ & 25.0 & 18.9 & 39.4 & 9.0 & 7.7 & \\
\hline & $\mathrm{f}$ & 317 & 65 & 41 & 05 & 16 & \multirow{2}{*}{4.49} \\
\hline $\begin{array}{l}\text { 35. I solve issues } \\
\text { honestly }\end{array}$ & $\%$ & 71.4 & 14.6 & 9.2 & 1.1 & 3.6 & \\
\hline
\end{tabular}


Table 4.5 shows that $46.6 \%$ of understudies at auxiliary level in region Muzaffarabad recommended that they generally state what they feel.14.4\% of understudies at the optional level proposed that they regularly state what they feel.32.4\% of understudies at an optional level in region Muzaffarabad proposed that they in some cases state what they feel while $2.9 \%$ understudies recommended that they infrequently state what they feel and just $3.6 \%$ understudies at auxiliary level in locale Muzaffarabad recommended that they don't state what they feel.

$70.7 \%$ of understudies at an optional level in region Muzaffarabad recommended that their instructor consistently trust them.16.2\% of understudies at the auxiliary level proposed that their educators regularly trust them.9.9\% of understudies recommended that their instructor some of the time trust on them while $1.4 \%$ of understudies proposed that their educator seldom trust on them and $1.8 \%$ of understudies at optional level in locale Muzaffarabad proposed that their educator don't trust on them.

$88.5 \%$ of understudies at an optional level in region Muzaffarabad proposed that their folks consistently trust them.7.2\% of understudies at the auxiliary level recommended that their folks regularly trust them.2.9\% understudies recommended that their folks now and then trust on them while $0.5 \%$ understudies proposed that their folks infrequently trust on them and just $0.9 \%$ understudies at auxiliary level in area Muzaffarabad recommended that their folks don't trust on them.

$67.6 \%$ understudies at an optional level in region Muzaffarabad proposed that their companions consistently trust on them.18.5\% understudies recommend that their companions regularly trust on them.11.0 \% understudies at an auxiliary level in area Muzaffarabad proposed that their companions here and there trust on them while $1.6 \%$ understudies at an auxiliary level is proposed that their companions infrequently trust on them and just $1.4 \%$ students at an optional level in region Muzaffarabad recommended that their companions don't trust on them.

$60.4 \%$ of understudies at an optional level in region Muzaffarabad proposed that they generally keep others' secrets.14.9\% of understudies at the auxiliary level recommended that they regularly keep others' secrets.16.7 \% understudies at the optional level proposed that they here and there keep others' privileged insights while $3.2 \%$ understudies at the auxiliary level proposed that they seldom keep others' insider facts and just 5.0\% understudies at optional level in area Muzaffarabad recommended that they don't keep others' mysteries.

$25 \%$ understudies at an auxiliary level in locale Muzaffarabad recommended that their companions and others in every case promptly keep their significant things with them.18.9\% understudies at the optional level proposed that their companions and others regularly promptly keep their important things with them.39.4\% understudies at the optional level proposed that their companions and others some of the time promptly keep their important things with them, while $9.0 \%$ understudies at the auxiliary level proposed that their companions and others seldom promptly keep their important things with them and just $7.7 \%$ understudies at an optional level in region Muzaffarabad recommended that their companions and others don't promptly keep their important things with them.

$71.4 \%$ of understudies at auxiliary level in locale Muzaffarabad recommended that they generally give genuine arrangement of the issue to their friends.14.6\%students at the optional level proposed that they regularly give legit arrangements of the issue to their friends. $9.2 \%$ of understudies at the auxiliary level recommended that they here and there give a fair arrangement of the issue to their companions, while $1.1 \%$ of understudies proposed that they seldom give a legitimate arrangement of the issue to their companions and just $3.6 \%$ understudies at an auxiliary level in region Muzaffarabad recommended that they don't give genuine arrangement of the issue to their companions.

Table 4.6 shows the impact of game involvement concerning time on social development

\begin{tabular}{lccc}
\hline Time in hours frequency & \multicolumn{2}{c}{ percentage } & mean score of social development \\
\hline \hline One hour & 173 & $38.9 \%$ & 3.74 \\
Two hour & 182 & $40.9 \%$ & 3.88 \\
Three hour & 33 & $7.4 \%$ & 4.41 \\
Four hour & 33 & $7.4 \%$ & 3.91 \\
More than four hours & 23 & $5.1 \%$ & 3.96 \\
\hline
\end{tabular}

The table shows that a larger part of the understudies (38.9\% and 40.9\%) went through 1 hour and 2 hours individually in a day in sports exercises. Table additionally shows that understudies who 
burned through 3 and over 3 hours were low in rate $(7.4 \%, 7.4 \%$, and $5.1 \%)$ however were high in social improvement with mean score of $(4.41,3.91$ and $3.96 \%)$ individually. This implies that understudies who invested more energy in sports exercises have similarly more noteworthy social advancement scores.

Table 4.7

Effect of game involvement on improving societal attitude

\begin{tabular}{llllllll}
\hline Variable & Gender & $\mathrm{N}$ & Mean & Std & $\mathrm{T}$ & $\mathrm{df}$ & $\mathrm{p}$-value \\
\hline \hline \multirow{2}{*}{ Self-Behavior } & Male & 277 & 32.47 & 3.33 & \multirow{2}{*}{-1.57} & \multirow{2}{*}{442} & \multirow{2}{*}{0.116} \\
& Female & 167 & 33.11 & 5.15 & \\
\hline
\end{tabular}

The $\mathrm{p}$-value is significant if $\mathrm{p} \leq 0.05$

Table 4.7 shows the correlation perspectives on male and female understudies taking an interest in sports exercises about the self-conduct at auxiliary level. Since $p=0.116>\alpha=0.05$. This implies that no huge distinction was found about the self-conduct of male and female understudy taking an interest in various games exercises at auxiliary level in region Muzaffarabad.

Table 4.8

Effect of game involvement on improving societal attitude of friendship.

\begin{tabular}{llllllll}
\hline Variable & Gender & $\mathrm{N}$ & Mean & Std & T & df & p-value \\
\hline \hline \multirow{2}{*}{ Friendship } & Male & 277 & 25.05 & 4.24 & \multirow{2}{*}{-.124} & \multirow{2}{*}{442} & \multirow{2}{*}{.901} \\
& Female & 167 & 25.00 & 3.98 & & & \\
& & &
\end{tabular}

Table 4.8 shows the correlation of the perspectives on male and female understudies taking an interest in sports exercises about the kinship at the optional level.

Since $\mathrm{P}=0.901>\alpha=0.05$, which implies no noteworthy contrast was found about the kinship of male and female understudy taking an interest in various games exercises at an optional level in region Muzaffarabad.

Table 4.9

Effect of game involvement on improving societal attitude of social behavior.

\begin{tabular}{llllllll}
\hline Variable & Gender & $\mathrm{N}$ & Mean & $\mathrm{Std}$ & $\mathrm{T}$ & $\mathrm{df}$ & $\mathrm{p}$-value \\
\hline \hline \multirow{3}{*}{ Social Behavior } & Male & 277 & 28.53 & 3.84 & & & \\
& Female & 167 & 31.23 & 3.91 & -7.12 & 442 & 0.000
\end{tabular}

Table 4.9 shows the examination of the views of male and female understudies partaking in sports exercises about the social conduct at an optional level. since $p=0.000>\alpha=0.05$. This implies no huge contrast was found about the social conduct of male and female understudy taking an interest in various games exercises at auxiliary level in region Muzaffarabad.

Table 4.10

Effect of game involvement on improving societal attitude of building confidence.

\begin{tabular}{llllllll}
\hline Variable & Gender & $\mathrm{N}$ & Mean & Std & t & df & p-value \\
\hline \hline \multirow{2}{*}{ Building Confidence } & Male & 277 & 18.47 & 3.14 & \multirow{2}{*}{.703} & \multirow{2}{*}{442} & \multirow{2}{*}{0.483} \\
& Female & 167 & 18.26 & 2.97 & & & \\
\hline
\end{tabular}

Table 4.10 shows the correlation of the views of male and female understudies partaking in sports exercises about the structure certainty at an optional level. since $p=0.483>\alpha=0.05$., which implies no huge distinction was found about the structure certainty of male and female understudy partaking in various games exercises at auxiliary level in region Muzaffarabad.

Table 4.11

Effect of game involvement on improving societal attitude of Honesty.

\begin{tabular}{llllllll}
\hline Variable & Gender & $\mathrm{N}$ & Mean & Std & T & df & p-value \\
\hline \hline \multirow{2}{*}{ Honesty } & Male & 277 & 29.56 & 3.77 & \multirow{2}{*}{-3.24} & \multirow{2}{*}{442} & \multirow{2}{*}{0.001} \\
& Female & 167 & 30.67 & 2.96 & & \\
\end{tabular}

Table 4.11 shows the examination of the perspectives on male and female understudies taking an interest in sports exercises about the trustworthiness at auxiliary level. Since $p=0.001>\alpha=0.05$. Which implies no huge distinction was found about the genuineness of male and female understudy taking an interest in various games exercises at auxiliary level in area Muzaffarabad. 


\section{Discussion}

The effect of sports investment on social improvement at the auxiliary level in locale Muzaffarabad AJK was investigated through review strategy by five scale. For the estimation of the social improvement of understudies at an optional level, a self-created survey comprising of five classifications was utilized. Purposive and arbitrary testing method was utilized to get the examination test from understudies' for example self-conduct, kinship, social conduct, building certainty, and Honesty. In this investigation, 444 understudies were chosen from various public-area schools of locale Muzaffarabad. The outcomes for various proportions of social improvement are examined in the accompanying lines.

\section{Self Behavior}

The outcome demonstrated that the understudies who take an interest in sports at the auxiliary level grow socially more than the individuals who do not partake in such exercises. Sports show the youth's sportsmanship, poise, tolerance, and consistency. This is the thing that develops self-conduct of the understudies. It has additionally been discovered that self-conduct of male and female understudies are improving similarly through games, and no huge contrast has been found in the self-conduct of male and female competitors.

\section{Friendship}

The consequence of this examination indicated that the understudies who take an interest in sports exercises build up a solid obligation of kinship with their kindred understudies and sportsmen. This investment in sports diminishes their confinement and gives them bliss and joy, augments their relationship with others, mingles them, and augments their relational abilities also. This outcome is steady with Hoye, Nicholson, and Brown (2013) just as with Sabin and Marcel (2014). No critical contrast was found between the self-conduct of male and female games members. It implies sports develop self-conduct of male and female understudies similarly.

\section{Building Confidence}

It is clear from the aftereffects of this investigation that sports interest fabricates trust in understudies of optional level, who partake in sports activities. Lullo and Van (2006) propose that games can expand a youngster's satisfaction and self-confidence. Sherry and Strybosch (2012) additionally found similar outcomes. Additionally, Hanks and Eckland (1976) also found that the university professor's contribution to curriculum practices such as sports provided two main competencies for the school. Establish and reinforce an instructive goal by arranging networking, helping to associate subordinates with schools and its guidelines, and helping to achieve that goal by involving subordinates through individual means such as social skill and courage. The findings also demonstrated that athletics collaboration similarly develops self-assurance in men and women sub-subjects.

\section{Goodness}

The reality between the two is in critical contrast the perspectives on male and female understudies partaking in various games exercises at an optional level in locale Muzaffarabad. This examination demonstrated that investment in sports exercises builds up the nature of genuineness among sports members. A socially very much created individual is consistently fair and dependable. A decent athlete is relied upon to be straightforward in sports rivalries, yet also in day by day life. He/she concedes his/her mix-up in-game regardless of whether arbitrator or rivals could not note it. The same is his/her conduct in the affairs of everyday life. The aftereffects of this examination likewise demonstrated that male and female competitors learn/build up the nature of legitimate similarly because of sports cooperation.

\section{Conclusions}

The destinations of this examination were to explore the effect of sports interest on social advancement of the understudies at auxiliary level in locale Muzaffarabad and to analyze the social improvement of male and female understudies because of sports cooperation. After investigating the information assembled from test members, the specialist comes to the result that dynamic cooperation in sports help in building up the social characteristics, for example, self-conduct, friendship, socialbehavior, building certainty and genuineness among the members. These characteristics are parts of the social turn of events, as the writing survey shows.

The scientist additionally arrived at the resolution that sexual orientation does not has any impact on the consequence of sports interest for social advancement of understudies at the auxiliary level in area Muzaffarabad. He reasoned that there is a similarly certain effect of sports investment on 
male and female understudies concerning different proportions of social advancement such as selfconduct, fellowship, fearlessness, social conduct, and trustworthiness.

\section{Conflicts of Interest}

We all the authors have approved the final manuscript and declare no conflict of any financial or other interest.

\section{References}

Audit Commission for Local Authorities and the National Health Service in England and Wales. (2009). Means to an end: joint financing across health and social care. Audit Commission.

Baciu, C., \& Baciu, A. (2015). Quality of life and students' socialization through sport. ProcediaSocial and Behavioral Sciences, 209, 78-83.

Bailey, H. R., Kurby, C. A., Giovannetti, T., \& Zacks, J. M. (2013). Action perception predicts action performance. Neuropsychologia, 51(11), 2294-2304.

Burgess, T. F. (2001). A general introduction to the design of questionnaires for survey research. Leeds: University of Leeds.

Cohen, L., Manion, L., \& Morrison, K. (2000). Research methods in education [5 th edn] London: Routledge Falmer. Teaching in higher education, 41, 21.

Gao, Z., Hannon, J. C., Newton, M., \& Huang, C. (2011). Effects of curricular activity on students' situational motivation and physical activity levels. Research Quarterly for Exercise and Sport, 82(3), 536-544.

Gemar, A. (2020). Sport as culture: Social class, styles of cultural consumption and sports participation in Canada. International Review for the Sociology of Sport, 55(2), 186-208.

Groves, R. M., Fowler Jr, F. J., Couper, M. P., Lepkowski, J. M., Singer, E., \& Tourangeau, R. (2011). Survey methodology (Vol. 561). John Wiley \& Sons.

Macphail, A., Gorely, T., \& Kirk, D. (2003). Young people's socialisation into sport: A case study of an athletics club. Sport, Education and Society, 8(2), 251-267.

Sabin, S. I., \& Marcel, P. (2014). Group cohesion important factor in sport performance. European Scientific Journal, 10(26).

Turcu, D. M., \& Todor, R. (2010). Socialization through sport. Effects of physical education and sport. The Annals of the "Stefan cel Mare" University V, 5, 128. 